\title{
Formation of a Person's Will to Commit a Legally Significant Act
}

\author{
Vladimir M. Syrykh* \\ Russian State University of Justice \\ 69 Novocheremushkinskaya Str., Moscow, \\ 117418, Russia
}

Received 05.03.2018, received in revised form 30.05.2018, accepted 08.06.2018

The article demonstrates that traditional neglect to the processes of formation of a person's will to commit legally significant acts by the positivist doctrine leads to an incomplete and unilateral study of the mechanism for the implementation of the norms of law, from which the real life of law, as well as complex and contradictory assessments and actions of the subjects of law that are of great significance and, above all, of persons, are omitted. The doctrine, accordingly, simplifies the processes for persons' choice of options of legally significant behavior and the role of state coercion in ensuring stable law enforcement in a society and a state. Meanwhile, the process of formation of a person's will to commit legally significant acts goes through four stages: 1) the choice of the object of legal relationship; 2) determination of a variant of legally significant acts capable of ensuring obtaining the object of legal relationship; 3) systematization of legal provisions, which a person is going to be guided by in the process of entering into legal relationship and fulfilling the obligations assumed; 4) formulation of the terms of the agreement, which a person plans to make upon entering into specific legal relationship. A person's choice of compliance with the law depends not only and not so much on the direction of his/her will, as on the economic financial situation. Economic viability, provided by the appropriate material resources of a person, is the primary condition for his/her legal activity in the field of private law. An economically insolvent person, who is permanently for a long time included into the number of economically needy people, is partially incapacitated in the legal sense, despite his/her formal, constitutional equality with others, including representatives of the social strata of society. At the same time, the fact that in the process of his/her will formation to perform legally significant acts an economically active person, as a rule, forms a system of rules of how he/she should act within the limits determined by law to ensure the achievement of the planned positive results, should be taken into account. The desire for material benefit is undoubtedly the fundamental factor in the choice of a legally significant behavior in the field of private law by a person, often prevailing over the principle of legitimacy and strong-willed orientations of the legislator.

Keywords: law, person, will, legally significant acts, private law, economic viability, legal capacity, individual right, stages of will formation.

DOI: 10.17516/1997-1370-0289.

Research area: law.

(C) Siberian Federal University. All rights reserved

* Corresponding author E-mail address: svm27@mail.ru 
It is a well-known fact that the positivist doctrine does not pay much attention to the forms of law enforcement used by the citizens at their discretion. It is believed that citizens do everything by themselves, automatically, without any worries, emotions and reflections. D.A. Chukhvichev is confident that "No reasonable person can have doubts about the necessity of compliance with the norms of law. It means that in this case, the only task of the state is to convey the social purpose of legal norm to the mind of each person and society as a whole (as their role in the life of society is axiomatic only for the lawyer). It is necessary to foster legal culture among citizens, instill respect for the right and the law."'

And a citizen who is experiencing some hesitations concerning the practicability of implementing the law in force, should be reminded of legal liability. While in the good old days the appearance of the cap of the police chief was enough to pacify the villagers, then the compliance with the law of modern citizens is very successfully provided by the threat of the use of state coercion. Having learned about the reality of state coercion and its negative consequences, most members of the civil society are ready to fulfill any obligation arising from the law or an agreement. In real life, meanwhile, everything is much more complicated and diverse.

Positive law overcomes its abstract nature by its embodiment in specific legal relationships. It really works insofar as the interested subjects are guided by it in their actions and behavior. All Christians who have repeatedly thought about a rather tragic but inevitable moment of their biography - a meeting with inaccessible, standing at the gates of the paradise Apostle Peter, who most likely will not let them go into the pastures of Heaven - do not notice the fact that on this sinful earth they themselves perform the similar functions regarding positive private law. Only a person, in his/her own and sole discretion and conviction, solves an issue of which particular norm he/she prefers and opens the gate for its transition into a valid law. Not every current norm of private law is awarded with the high honor of being seen by a person and implemented in specific legal relationships. The further a legal norm is separated from the sphere of the person's immediate interests and consolidates the orders and values that are not shared by him/her, the less chances it has of being implemented in current, real life.

The process of forming a person's will to commit legally significant acts goes through four stages: 1) the choice of the object of legal relationship; 2) determination of a variant of legally significant acts capable of ensuring obtaining the object of legal relationship; 3) systematization of legal provisions, which a person is going to be guided by in the process of entering into legal relationship and fulfilling the obligations assumed; 4) formulation of the terms of the agreement, which a person plans to make upon entering into specific legal relationship.

At the first stage, a person determines his/ her will regarding the object of legally significant acts. His/her actions are necessarily directed at the subject able to meet the urgent need best. As soon as the necessary component of the legal relationships is an object - a specific material or spiritual good - then the will to enter into legal relationships is always determined with regard to the object of the legal relationships. The object is identified by a person according to its use value and is individualized according to particular characteristics. Legal relationships with an undetermined object are impossible, since its parties cannot make a contract or reach an agreement without determining the object and, accordingly, without specifying the legal obligations of the parties involved. 
Specific feature the first stage of the will formation consists in the fact that it forms not a legal, but an economic will. At this stage, a person acts as an economic agent and his/her will, accordingly, is not legal, but economic one. He/ she chooses a product that has a certain consumer value and can satisfy his/her needs. A person, in this case, most often makes a compromise between the consumer value of the goods and the available material needs. Everyone understands that the palaces of modern hierarchs represent the most comfortable environment for living, but a lot of people still have to live in Khruschevera houses not because they have modest accommodation requirements, but because they cannot claim for more due to the lack of sufficient material resources.

It is evident that under the conditions of market relations, a certain part of civil society living near or below the poverty line, have minimum opportunities for the dignified satisfaction of their material and spiritual needs, for the consumption that sustains life but does not allow to enjoy and benefit from the benefits of the civilization fully. In formally acting private law, however, there is no division of the society into social strata (the poor, middle class and economic hierarchs). Within its frames any financially capable person enjoys freedom and is an honorable participant in economic relations. A person who does not have the appropriate financial resources does not have a real economic and, accordingly, legal freedom. Therefore, according to G. Hegel's advice, "It is best to rely on their fate and give them the opportunity to beg openly."

Thus, before becoming a subject of private-law property relations, a person must be economically capable and have necessary financial resources. For an economically incapable person living near or below the poverty line the social and legal mechanism for the formation of individual private law for goods that require significant material costs, at best, ends with the stage of choosing the object of legal relationship, which he/she cannot obtain legally. A person has no choice but to be content with what is available or to be involved in committing illegal actions, to meet his/her needs illegally.

The will formation at the second stage is largely determined by the choice of the object that a person has chosen as the object of meeting the need, taking into account his/her financial resources and other conditions. Focused on performing actions within the legal framework, he/ she can choose one of the following three options: 1) to act in strict accordance with the current legislation; 2) to give preference to the customary law and other social norms; 3) to develop an original norm of law. A person independently and freely determines which of these ways of committing legally significant acts is the most appropriate for him/her and, having chosen the appropriate option, continues to implement it into reality, guided by the appropriate norms and the logic of actions necessary to achieve the intended result.

As a primary or alternative version of the legally significant acts, a person can plan to commit unlawful acts, which is fully covered by the concept of the freedom of will and is an act that does not entail legal liability as long as the intent remains an internal state of the potential offender. However, a person with this vision should either be guided by the shadow law norms or develops his/her original way of committing an offense which allows to avoid exposure and bringing to legal responsibility.

By choosing a specific variant of a legally significant act, a person can remain inactive for quite a long time, considering the plans for actions, but not daring to implement them into immediate reality. This requires a separate act of will that is expressed in the recognition of the necessity to act according to the plan chosen and 
corresponding to the system of the norms of law: positive, social, private or shadow. Further, the will should be demonstrated with respect to the legal provisions that logically follow the system of norms that strengthen the chosen variant of legally significant actions.

Having decided upon the variant of legally significant actions, a person forms his/her will regarding the system of norms that strengthen this variant. He/she initially needs to understand what requirements should be met to ensure that his/her actions correspond to positive law, other social norms or shadow law. The most difficult, most likely, will be the choice of normative regulations, defined by the positive law, as the most complex and developed system of norms. A person will need to identify and systematize the regulatory provisions of both the law and other normative legal acts that specify it.

At this stage, we are talking about systematization of regulatory directions, that, firstly, regulate the variant of the actions chosen by a person and, secondly, confirm the actions that he/she recognizes as optimal and best suited to his/her ideas about the ways of getting the object of the planned legal relationship. At the same time, the norms are still in their abstract generality, poorly correlated with the specific conditions in which a person plans to enter into legal relationship and exercise his/her subjective rights. At this stage of the will formation, however, nothing else is required. The main task is to determine, as they say, the strategic plan of action, how to act legally correct to achieve the expected result and, at the same time, not to incur arbitrary costs, not required by the logic of the matter.

A person will have to identify the legal norms regarding all the components of the planned legal relationship, as well as the procedure for entering into it and fulfillment of the obligations undertaken. Of course, it is possible not to make an insight into legal studies, the law does not force anyone to do this. A free-willed person can completely rely on another participant who can be experienced in such matters and foresees all the legal details in advance, everything has already been reflected in the existing standard variant of contract. But such an approach is fraught with the fact that the other party can shift a certain part of his/her duties to a trustful simpleton, and even decline all responsibility for the results of his/her activity. Therefore, in order not to be left with nothing, any economic person is unlikely to fully rely on his/her future partner in forming the legal side of the contract. He/she should thoroughly study the legal aspect of the future legal relationship.

For instance, a person who is tired of seeing his/her apartment that has not been repaired from the Soviet times and wishing to introduce modern household appliances into his/her daily life, arranging them in accordance with the requirements of Feng Shui, has decided to carry out repairs. At the same time, being aware how bad and even botched the repairs carried out by various construction brigade organizations can be, considered rational to use all the possible legal means to protect his/her financial interests and subjective rights when entering into an agreement. Therefore, the person paid particular attention to the norms that secure his/her rights, the procedure for their implementation and legal guarantees aimed if not to guarantee the proper quality of the repairs then to provide a decent compensation for the contractor's negligence. As a result of the interpretation and systematization of the norms of law obtained from various sources, he/she achieved the following results.

The contract should be made with an organization, but not with the brigade of people doing extra work, as only organization can give the repair warranty and is able to bear financial responsibility for poorly executed repairs. The 
contract should necessarily determine the types of repair, the requirements for the quality of the work performed, time limits for the separate repair stages, their cost and step-by-step labor payment, as well as the procedure for providing construction materials and garbage disposal. It is necessary to determine penal and other sanctions for the late performance of repair works and their low quality, the obligation of the organization to eliminate poorly performed repair works quickly and efficiently at its own expense, the grounds and the procedure for the contract termination on one of the parties' initiative particularly carefully. The person may single out other legal provisions that arise from the civil legislation and determine his/her initial legal positions which he/she must reflect in the contract in the form of specific conditions.

Although the legal provisions formulated by the person are based on the existing positive law they, nevertheless, contain the elements of the person's immediate creative work, just as the legal provisions of judicial practice are original regulatory decisions, authored by the judicial body but not by the legislator. According to P.A. Guk, judicial practice is a source of law since the judicial act of the supreme judicial body provides explanations on the application of normative legal acts, new procedural rules and legal provisions (judicial norm) by which a gap or a defect in the normative legal act has been overcome, have been developed and formulated ${ }^{3}$.

The forms of creative development of the current legislation by the judicial bodies represented in the legal provisions to various extent, are formulated by a person, since they are universal and applied in all the cases when there is a need for the creative development and specification of the law as applied to the specific conditions of the cognizing subject. A person assimilates and systematizes the norms of the current legislation in relation to the conditions of the planned legal relationships, therefore, he/ she supplements general rules of law with certain operational legal provisions that guide him/her how to act to fulfill these general requirements. Such legal provisions are necessarily derived by the person independently, as procedural norms are mostly absent in the legislation, whereas they are the essence of the case for the acting subject because legally competent actions are a necessary condition for the successful use of the substantive norms of law.

A person sees effective means of protecting his/her property interests in the formulated legal provisions and, therefore, perceives the will of the state expressed in laws as his/her own. But he/she will face another stage - the formulation of his/her will in the form of specific terms of the contract of the planned legal relationships, to transit from the universal right to the specific one, to give the objective law a form that brings it closer to the reality, to that only possible form in which universal acquires real existence, peace and finitude. A person is required to draft a contract, in which, from the position of his/her interests, it is necessary to specify both his/her rights and obligations and the rights and obligations of another participant of legal relationships and other essential conditions.

Not every person is able to draft a contract properly, but he/she is fully able to determine his/ her position on all the significant issues clearly and precisely. The more fully and clearly a person formulates his/her legal claims in the planned legal relationships, the more clearly he/she will be able to state and successfully defend his/ her position towards the other party of the legal relationships, as well as to ensure the consistent consolidation of these claims in the contract.

So, in our example, the person who wants to repair the apartment, among the essential terms of the contract, will strive to reflect most the legal provisions formulated by him/her at the stage of 
positive law specification. In particular, he/she most likely will make a list of works that must be performed during the repairs, the requirements that must be met by the works performed, the procedure for purchasing construction materials and construction waste disposal, as well as the conditions that construction workers must observe while in the premises that are being repaired. A particularly perspicacious person will try to determine penalties and other sanctions for the subcontractor for poor-quality and late performance of repair works, the grounds and procedure for termination of the contract on the customer' initiative, etc.

The process of forming a person's will with respect to legal requirements based on non-legal social norms or shadow law will have a similar scheme. It is conceivable that significance of a person's actions, focused on the creation of original norms of individual law and specifying their legal provisions can be strengthened in this process, since social norms, as well as shadow ones, do not have such a developed form as positive law and contain significant gaps. Filling in the gaps, a person will be forced to formulate the missing legal provisions and specific conditions of the contract independently, based on the logic of the matter and the content of the planned legal relationships. The success of such actions largely depends on the level of knowledge of the principles of law and morality, the norms of positive law and abilities for the intuitive creative work of a person.

In any case, a person who ignores the norms of positive law is previously doomed to his/her own law-making at the necessary minimum of the original norms capable of expressing and protecting his/her property or any other interest. Accordingly, a person willing to act successfully on the legal front appears in the society not only with the code in his/her hands, but also with an extensive list of conditions that he/she would like to reflect in the contract determining the content of the planned legal relationship.

A person who has successfully completed the stage of his/her will formation by defining the conditions that he/she would like to reflect in the contract has reached the highest form of individual law-making. The complex and contradictory process of law cognition led to the set goal fulfillment - the transition of the general, abstract, objective and corresponding positive law to the level of specific legal claims of a person, or, in other words, of his/her individual right. Due to a person's actions and diligence, objective law acquired a more specific form, making another significant step on the way of translation into reality.

The abovementioned way of individual right formation is not the only possible one. Along with it, a simplified way, when a person enters into legal relationships without bothering him/herself with long and troublesome reflections on the topic of what his/her interest is and what his/her rights should be, is used. A simplified process of individual law enforcement is practiced in three forms.

The first form is characterized by the absence of the need to study the rights and responsibilities by a person. Such situations most often arise when entering into the standard domestic legal relationships associated with meeting the needs for the goods of prime necessity: food, clothing, outdoor activities, etc. First, because the rights and obligations of the parties in such legal relationships are standard and nothing new can be introduced into them. Secondly, a person is well aware of both his/her own and the second party's rights and responsibilities in the planned legal relationship. Thirdly, the content of the legal relationship is determined by the service provider, and the service recipient cannot change them for his/her benefit (standard form contract and adhesion contract). 
The second form of reduced individual right enforcement can arise in a situation when a person entering into legal relationship does not attach much importance to the processes of clarifying his/her rights and obligations in the planned legal relationship, although he/she could and should have paid special attention to them. The person fully relies on the other party to the legal relationship, his/her honesty and conscience. But, as has already been mentioned, in this case he/she risks being left without meeting his/her needs, as well as the resources spent on getting the subject of need. Modern practice knows plenty of those who want to purchase additional goods without violating the rights of others, only at the expense of their unreasonable legal activities.
The third form of reduced individual right enforcement takes place in cases when a person commits legally significant acts under the influence of emotions caused by some external circumstances, sometimes being unaware of the acts performed.

Individual law enforcement which aims to thoroughly identify the legal aspects of the planned legal relationships by the actor is, thus, the most effective guarantor of protecting rights and freedoms of a person from endeavors on the part of other persons. Anyone who wants to preserve and increase his/her material wealth and to operate in the sphere of private-law relationship successfully should rise to the level of the individual right formation.

Chukhvichev, D.V. (1996). Ubezhdenie kak forma gosudarstvennogo obespecheniia normy prava [Persuasion as a Form of the Public Provision of the Norm of Law], In Pravovedenie [Legal Studies], 2. Available at: http://www.law.edu.ru/article/ article.asp?articleID=151517 (Accessed: 20.02.2018).

2 Hegel, G. (1990). Filosofiia prava [Philosophy of Right]. Moscow, 272.

3 Guk, P.A. (2012). Sudebnaia praktika kak forma sudebnogo normotvorchestva v pravovoi sisteme Rossii: obshcheteoreticheskii analiz: avtoref. ... d-ra iurid. nauk [Judicial Practice as a Form of Judicial Rule-Making in the Legal System of Russia: General Theoretical Analysis: Author's Abstract ... Doctor in Law]. Moscow, 27.

\section{References}

Chukhvichev, D.V. (1996). Ubezhdenie kak forma gosudarstvennogo obespecheniia normy prava [Persuasion as a Form of the Public Provision of the Norm of Law], In Pravovedenie [Legal Studies], 2, 121-133. Available at: http://www.law.edu.ru/article/article.asp?articleID=151517 (Accessed 20.02.2018).

Guk, P.A. (2012). Sudebnaia praktika kak forma sudebnogo normotvorchestva v pravovoi sisteme Rossii: obshcheteoreticheskii analiz: avtoref. ... d-ra iurid. nauk [Judicial Practice as a Form of Judicial Rule-Making in the Legal System of Russia: General Theoretical Analysis: Author's Abstract ... Doctor in Law]. Moscow, 50 p.

Hegel, G. (1990). Filosofiia prava [Philosophy of Right]. Moscow, Mysl', 524 p. 


\title{
Формирование индивидом воли
}

\section{на совершение юридически значимого действия}

\author{
B.М. Сырых \\ Российский государственный университет правосудия \\ Россия, 117418, Москва, ул. Новочеремушкинская, 69
}

\begin{abstract}
В статье показывается, что традиционное невнимание позитивистской доктрины к процессам формирования индивидами воли на совершение юридически значимых действий приводит к неполному, одностороннему изучению механизма реализации норм права, из него выбрасывается реальная жизнь права, сложные и противоречивые, но имеюшие первостепенное значение оценки и действия субъектов права и в первую очередь индивидов. Соответственно доктрина упрошает проиессы выбора индивидами вариантов юридически значимого поведения и роли государственного принуждения в обеспечении устойчивого правопорядка в обществе и государстве. Между тем процесс формирования воли индивида на совершение юридически значимых действий проходит четыре этапа: 1) выбор объекта правоотношения; 2) определение варианта юридически значимых действий, способных обеспечить получение объекта правоотношения; 3) систематизация правоположений, которыми индивид полагает руководствоваться в проиессе вступления в правоотношения и исполнения взятых на себя обязательств; 4) формулирование условий договора, который индивид планирует заключить при вступлении в конкретное правоотночение. Выбор индивидом правомерного поведения зависит не только и не столько от направленности его воли, сколько от экономического материального положения. Экономическая дееспособность, обеспеченная надлежащими материальными ресурсами индивида, является первостепенным условием его юридической активности в сфере частного права. Недееспособный в экономическом отночении индивид, устойчиво, на протяжении длительного времени входящий в число материально нуждающихся лиц, является ограниченно дееспособным в юридическом смысле, несмотря на его формальное, конституционное равенство со всеми, в том числе и представителями социальных слоев общества. Одновременно нужно учитывать, что экономически дееспособный индивид, формируя свою волю на совершение юридически значимых действий, как правило, формирует для себя систему правил, каким образом, ему следует действовать в рамках, определенных законом, чтобы обеспечить достижение планируемых позитивных результатов. Желание материальной выгоды, несомненно, является основополагающим фактором выбора индивидом юридически значимого поведения в сфере частного права, нередко превалирующим перед принципом законности и волевыли установками законодателя.
\end{abstract}

Ключевые слова: закон, индивид, воля, юридически значимые действия, частное право, экономическая дееспособность, юридическая дееспособность, индивидуальное право, стадии формирования воли.

Научная специиальность: 12.00.00 - юридические науки. 